This item was submitted to Loughborough's Research Repository by the author.

Items in Figshare are protected by copyright, with all rights reserved, unless otherwise indicated.

\title{
Learning from water sector reforms in Europe and Asia
}

PLEASE CITE THE PUBLISHED VERSION

PUBLISHER

(C) Thomas Telford Ltd

VERSION

AM (Accepted Manuscript)

LICENCE

CC BY-NC-ND 4.0

REPOSITORY RECORD

Sohail, M., and Olena Maslyukivska. 2019. "Learning from Water Sector Reforms in Europe and Asia". figshare. https://hdl.handle.net/2134/5316. 
This item was submitted to Loughborough's Institutional Repository (https://dspace.lboro.ac.uk/) by the author and is made available under the following Creative Commons Licence conditions.

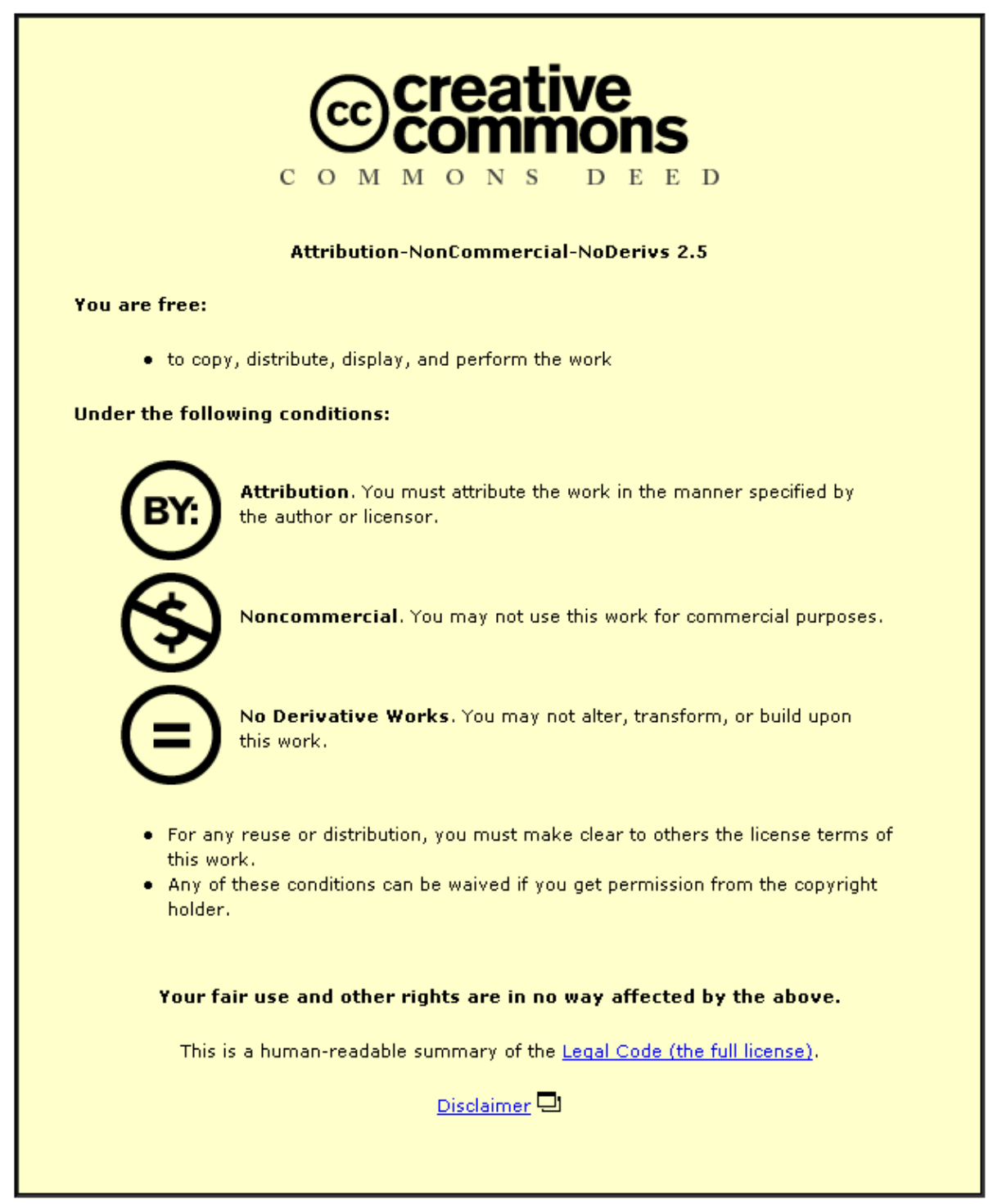

For the full text of this licence, please go to: http://creativecommons.org/licenses/by-nc-nd/2.5/ 
Learning from partnership experiences and water sector reforms in the Eastern and Central Europe and Central Asia region

M. Sohail ${ }^{1}$ and Olena Maslyukivska ${ }^{2}$

Key words: Contracting, Water supply

${ }^{1}$ BEng, MSc, PhD (UK), Fellow ASCE (USA)WEDC, Loughborough University, UK

${ }^{2}$ Senior Lecturer of Environmental Economics, National University of "Kyiv-Mohyla Academy", Ukraine 


\section{Introduction}

The Eastern Europe and Central Asia (ECA) region has a population of 480 million, of which 66.5 per cent lives in urban settings. The ECA region is unique when compared to other regions as it has highly developed urban systems and relatively high service coverage. Although some parts of the local utilities were built under the communist period (e.g. district heating, expansion of water services, waste water treatment plants), the majority of water and sanitation infrastructure is on the verge of collapse; Presently private operators serve only 30 million, or 6 per cent of inhabitants. Moreover, these 30 million people live predominantly in capitals or large cities.

The involvement of the private sector in partnership with government has been advocated as a means of improving the development of sustainable infrastructure systems. 'Public Private Partnership' (PPP) is used in this paper as a general term covering a wide range of partnerships between utilities, governments and communities in order to improve/ maintain existing infrastructure and to extend services.

Governments turn to PPP arrangements for the provision of urban services for a variety of reasons. These may include increasing urbanisation, incapacity of government to keep pace with service provision, financial difficulties and the ensuing difficulties of funding public infrastructure and services. In addition, International Financial Institutions (IFI) require that certain indebted countries reduce domestic spending as part of Structural Adjustment Programmes. IFIs promote the idea that private sector is more efficient and produces a better quality service. Given that privatisation of infrastructure sectors tends to occur in the context of broader economic reforms it is important to register their effects on poorer households in developing countries.

Private Public Partnerships have been hailed as a means to overcoming budgetary shortages/ financial constraints, poor managerial capacity, systematic problems of inefficiency, lack of cost recovery/ uneconomic levels of tariffs and technical know how. However, water and sanitation sectors have attracted the least interest from the private sector after telecommunications, energy and transport. The reason for this trend may be the difficulty in introducing competition into the sector, stateownership and it's unattractiveness as an investment.

Is this paper we refer to the broad PPP schemes spectrum of options from simple service contracts of operation and management to privatization (sale of assets) where only regulatory powers are left with the client government 1 . Current trends in private-sector participation in infrastructure suggests concession, lease and BOT type contracts and possible service contracts, appear to be the most common, and full privatisation (divestiture) model is least popular. The predominance of concessions and leases is due to their perceived attractiveness by both public and private sectors. The appeal to the public sector is in the reduced risk of partnership with the private sector that these models offer and the appeal to the private sector is in the potentially high returns.

It is the purpose of this paper to review partnerships in the infrastructure sector in ECA region and to present emerging lessons. One of the most critical problems in evaluating the past 
decades of corporatization and privatization in the local utility sector is that there are no reliable data. This paper is based on data collected on the experience of the 28 ECA countries with regards to PPPs involving international operators 2. The study included analysis of OECD/DANCEE reports, reports available on the internet, regional data published in periodical issues and other relevant information [2, 9-12, 14]. Information was also gathered through contacts with academic institutions conducting related research, government offices, water utilities and regulators, polling agencies, journalists, consumer associations and local and regional NGOs. Cases from across the region are presented to illustrate:

- different types of PPP(management, lease, concession, BOT).

- the various motives for entering a PPP,

- key stakeholders in the process,

- the degree of local participation in the project.

- the number of transactions

- amount of investment

In particular, it draws on work that is being carried out in the framework of a joint OECD DANCEE project in Czech Republic, Estonia, Hungry and Poland [14], which provides a detailed analysis of the differences in approaches taken in four focus countries in the water and sanitation sector : the Czech Republic, Estonia and Poland for PSP in the water sector, including policies, as well as social and political aspects.

Based on the survey, one can see that although there is no domination of a particular type of contract in the region, service contracts (lease and O\&M) are standing out as the most used framework for PPP, see Table 1 below.

\section{Public-Private Partnerships in the region}

The ECA region is unique compared to other regions as it has highly developed urban systems and relatively high service coverage. However, the infrastructure is on the verge of collapse being that it is over 40 years old and has suffered poor maintenance during the last 10 years. The trend towards the decentralization of infrastructure services in the region started in the mid-1990s, with major responsibilities transferred to the municipalities. Since 1992 private sector involvement in the water and sanitation sector in the region has increased at a steady pace; however, private sector operators still serve only 6 per cent of inhabitants.

Several factors contribute to partnerships in the water and sanitation sector. On the one hand, pitiful underinvestment and an urgent need for upgraded and expanded infrastructure pressurize the search for alternatives to public sources of funding. On the other, inefficiencies, lack of modern operating and managerial techniques and limited access to technologies encourage partnerships with those who do have this expertise. Finally, the convergence with the EU regulations promoted the private sector involvement in the new EU countries and the candidates.

The major benefits from private sector involvement in infrastructure in the region are manifested in the transformation of old water companies into more dynamic businesses. Involvement of private partners has helped to rationalize utility companies, increasing efficiency and decreasing the unit cost of services. Moreover, there has been increased focus on customers, improved customer relations and increased billing and collection rates. Leakages were also reported to be declining, while in a few cases the quality of water has also increased. 
The status of PPPs in the infrastructure sector differs among countries in the region. A number of factors account for these differences. These include: institutional capacity; regulatory changes; the state of the water and sanitation sector before the transition from a planned to a market economy; the extent of reforms undertaken so far; the macro-economic performance of the countries concerned; levels of household income; and the availability of external assistance. While some countries seem to have experienced considerable success in their utilities' institutional and financial performances, in other countries infrastructure services are still in the midst of a severe crisis.

European Union accession has become one of the important external factors affecting private sector involvement. For the accession countries the cost of compliance with EU standards can be measured in billions of US dollars, amounts that could not be provided by the governments alone. The pre-accession funds, such as ISPA and PHARE, have been designed to provide some of the investment necessary for compliance with EU standards; however, even this funding is not sufficient. The gap between the required investments into infrastructure rehabilitation and expansion and the available internal and external funding is still significant. The private sector has been called in to bridge this gap.

\section{Region's division according to the interest to the private sector}

In order to attract the private sector to expand its involvement in the region, external support is needed for almost all countries in the region. The region can be divided into four groups according to potential for private sector involvement based on the number of microeconomic characteristics (GDP growth, inflation rate, etc.) and indices (e.g. economic liberalization, corruption). such as GDP growth, . Table 2 provides a classification of the countries by dividing them according to "interest" or "attractiveness". These country groups also represent stages of development (from 4 to 1). For group 1, this support manifests in infrastructure rehabilitation and expansion of financing, and in finding some way of partially covering the transaction costs. First-tier EU accession countries have already undertaken significant sector reforms and have created working legislative frameworks. A vivid example is the Czech Republic, where three-quarters of the water sector has PPPs. For group 2, this support needs to aid regulatory and tariff reform. Many of the group 2 countries are of considerable interest for PPP for example Estonia was considered advanced in its economic strategy and willingness to embrace PPP but is constrained by its size. For groups 3 and 4, only the international community can facilitate private sector involvement; first and foremost in these countries, there is a need for reform in the water and sanitation sector, as well as reform in the institutional and legal frameworks. Russia and Ukraine are developing their PPP initiatives and there has been considerable progress during the last two years. In particular, domestic private sector takes increasingly active role in providing water, energy and heating services in Russia. Ukraine is preparing the law on PPPs and makes amendment to the Concession Law with the purpose to utilize the PPP scheme for its overwhelming infrastructure investment needs. 


\section{Public and/or political perceptions of PPP in the region}

Public perception of PPP in the region ranges from favorable to indifferent. The following factors were found to contribute to the sensitivity of the public towards PPP in the focus countries.

1. Lack of transparency during contract tenders and negotiations. For instance, in the Czech Republic Vivendi Water (now Veolia Water) paid an amount three times more than that offered by other bidders, raising media attention and suspicion.

2. Labor issues related to the water utility privatization. In the cases when the private operators negotiated with the trade unions through labor reduction schemes (through compensation packages or retirement), negative media commentaries were absent.

3. Political cycle, i.e. election campaigns. For instance, in Estonia the Tallinn ex-City Council Chairman Edgar Savisaar lowered water tariffs in the city as an obvious election ploy just before the 1999 local election ${ }^{3}$. Closer attention is paid to the researched sector during election times.

4. Quality of services. The deterioration of services is a key issue when the water is supplied by a private operator.

An economic survey of the Central European Opinion Research Group (CEORG) shows a generally positive attitude of the public in the Czech Republic, Slovenia and Hungary towards the foreign private sector. The study revealed that more then half respondents (55\%) in Hungary think that the foreign direct investment will improve the national economy; $46 \%$ prefer to see foreign private companies to own the minority stake in the domestic companies and $8.5 \%$ considering that the majority share will improve the local economy. The Czech respondents would rather see a foreign company to establish a new business (27\%), 23\% agree that the minority stake and $13,4 \%$ that the majority stake will benefit the country. ${ }^{4}$ The majority (36,5\%) did not have any opinion on the impact of the foreign direct investment on the economy.

The price for services, however, could become the most sensitive issue for the ECA countries. With a few exceptions, these countries tend to keep water prices low. Thus, private operator involvement, accompanied by the tariff increase, could raise public protests as people are not willing to pay more for public goods like water.

Political perceptions differ from country to country depending on the ruling party. Hungary provides a good example. Belarus and Moldova, meanwhile, do not favor private sector involvement in the water and sanitation sector. Thus, protests against PPP are to be expected in these countries where the image the private sector is not positive. It is concluded that previous successful involvement of the private sector in any particular country's economy influence the perception of the PPP in the infrastructure sector

\section{Situational analysis to assess the levels and impacts of PPP in four countries in the region}

PPP in the water and sanitation sector was examined in four focus countries: the Czech Republic (CZ), Estonia (E), Hungary (HU) and Poland (PL). These countries all had similar starting positions at the beginning of their transformation from planned to market economies; they also all currently enjoy high economic development. Despite these similarities, the four countries have ended up with different degrees of PPP, with the Czech Republic being a clear leader, followed by Hungary and Poland. Estonia, a newcomer to the PPP scene, is forming a 
different model of PPP in small countries, having water utilities run by both the international private sector and its domestic private sector. Models of privatisation also vary; the Czech Republic used a rapid and mass voucher model of privatization, whereas the Estonia, Hungary and Poland chose a case-by-case sale approach.

The focus countries contribute two-thirds of the region's PPP projects, where 40 projects serve 14.5 million people. Despite similar initiatives early on in the transition period, these four countries ended up with different levels of PPP. The Czech Republic is the leader in PPP in water in the entire ECA region (with 24 PPP projects). Here the private sector serves 25 per cent of the entire CEA region's population.

Analyzing the historic patterns of PPP in water, as well as legal and institutional developments in each country, the authors identified four different models of PPP in countries with very similar levels of economics development. This approach could be of assistance when recommending PPP options to the other ECA countries.

\section{Models of PPP in water and sanitation}

\section{CZECH MODEL SUMMARY: LET THE MARKET DECIDE}

The Czech model of PPP in water and sanitation is recommended for a country that is willing to move as quickly as possible to involvement of the private sector. It is a model that includes decentralization and corporatization of the country's water utilities, with maximum rights allocated to the municipalities and minimum control from the governmental side.

The Czech model can be used by authorities who wish to maintain asset ownership in the public sector, while using the private sector for operations. This approach not only brings in the private operators' experience and management practices, but also fulfills the requirements of the municipal budget.

\section{A. Current status}

Currently, the Czech Republic (CZ) is an example of an atomized and largely privatized market. After decentralization the Czech Republic found itself with about 800 water operators, 126 of which were responsible for 96 per cent of the water service provision, the water market is clearly divided among three international water companies: Veolia Water (before 1 May 2003, Vivendi Water), Anglian Water, and Ondeo (formerly Lyonnaise des Eaux). After a rapid private sector involvement in late 1990s, the pace of PPP slowed down due to the limited supply of operational contracts. The big operators are now buying smaller companies in the area of their service activities (including from each other). ${ }^{5}$ In the Czech Republic the trend exists towards takeovers of the smaller companies by the three major foreign owners. However, municipalities in Eastern Bohemia kept the services under government control. 
After privatization, the CZ statistics reported a steady decrease in water leaks and losses. Moreover, as a result of private sector participation, the efficiency of the privatized companies slightly increased through:

- control of operating costs;

- negotiations with the suppliers;

- increased output per person employed; and

- billing and payment improvements (The non-payment level constitutes about 5

7per cent. On average the water bills are 1 per cent of the household income).

- No technology transfer was reported.

Before privatization, the quality of drinking water was compliant with the highest EU standards. With private sector involvement, water quality became even better because the new operators started using new chemicals to treat water. In addition, because of the tariff increases, the demand for water decreased; this also had an impact on water quality.

Customer service was witnessed to have improved; however, an average Czech is unlikely to be aware that the water he/ she is using is provided by a private company.

Public perceptions of PPP in CZ are not well developed. Although during the process of privatization the press paid close attention to the fact that private operators were entering the market, most of ordinary Czechs are not aware or are unconcerned about the fact that their water is provided by the international operators.

Labor issues did not lead to any unrest as the workforce reductions that have taken place at the waterworks with PPP have been occurring gradually with the targeted groups being people of pensionable age. Since 1993 about one third of the employees of privatized organizations have been made redundant.

Corporate social responsibility varies across municipalities. Overall, standardized rules applied from the Western European experience is the most common change reported.

\section{B. Process of getting there}

Reforms in the water sector in Czech Republic have been initiated from the top down. Water sector privatization followed the overall Czech mass and rapid voucher privatization model.

The principal change effected over the past ten years has been the decentralization of the water supply sector, which transferred the responsibility for and ownership of the public water supply from the central government to municipalities. The assets were transferred 'free-ofcharge.' There was no standard form of transfer, and this led to fragmentation.

As soon as the municipalities became owners of the water companies, more then two-thirds of them decided to separate the infrastructure from the operational assets, which have values corresponding to about 95-97 per cent and 3-5 per cent respectively. This separation enabled the municipalities to encourage private companies to bid on the operations contracts. As a result, as of now, all those water companies that separated their operations from their infrastructure assets have private companies managing the water utilities under predominantly lease contracts. The other third of municipalities (primarily those in Eastern Bohemia) decided not to separate the infrastructure assets from operations, and there is no private sector involvement so far in this region. 
Water tariffs traditionally were too low and did not cover operating costs. Thus, the Czech government decided to bring tariffs up to cost recovery levels. By May 15, 1993 the reform was completed and since then the operations of water supply and sewerage have not been subsidized. At the local level there are only a few examples where services are provided to individual or corporate consumers at a reduced price as a result of city or community subsidy.

\section{Obstacles for deeper PPP}

Although the Czech water market has the most of private sector involvement, its weak regulatory basis has created a situation in which the national government does not possess any mechanisms or tools to regulate the market effectively. Until 2006 there was no concession law in the Czech Republic, thus the majority of private sector projects were based on primarily leasing. The concession law was legislated in July 2006: Act No. 139/2006 Coll., on Concession Contracts. Together with the creation of the PPP Centrum in 2004 the law enables more private sector involvement. However, a number of obstacles still hinder the further involvement of PPPs in the Czech Republic water sector:

1. Over-fragmentation.

2. Loss of control over the privatized water industry when there is no one national body regulating the water sector specifically.

3. Absence of the public tenders on operations.

4. Lack of transparency at tenders.

5. Capacity of local management. The lack of necessary technical and administrative capacity has been proven to slow down the work of the private companies. Lack of capacity by the municipalities to bargain with more professional and experienced private experts.

6. The classical PPPs was started with a delay and in large cities only

7. Municipalities in Eastern Bohemia kept the services under government control.

\section{Hungarian Model}

\section{HUNGARIAN MODEL SUMMARY: SLOW BUT STEADY}

The Hungarian model of PPP in water and sanitation is recommended for a country that would like to see its water utilities moving away from public control. It is also an illustration of strategic investors' consideration of each privatization on a case-by-case basis. Such a model is especially viable in any situation where there exist strong trade unions and a strong NGO sector.

Necessary steps in this model include decentralization and corporatization of the water utilities and control of any excessive fragmentation that may result.

This model will not lead to rapid private sector involvement; rather, it will slow down the process. However, it will ensure a high degree of quality in the projects, and it is a model that takes into account voice of the public.

\section{A. Current situation}


Hungary provides a case study of different models of ownership of services within the same country and in the water and sewerage sector. Presently there are seven PPP projects working in the county; however the private partner does not own the company in any of these projects due to legal constrains. The private water market is dominated by foreign operators, such as Veolia (formerly Vevendi), ONDEO Services (formerly known as Lyonnaise des Eaux), RWE, Berliner Wasser and Gelsenwasser.

100 per cent of customers were satisfied with general water services provided by the Budapest Water Company, and 60-80 per cent was satisfied with additional services. No protests against privatization of the water sector were detected. However, soon after the beginning of changes in the Budapest Water Company, social concerns arose over the fact of workers' dismissals. However, most of the dismissed people were approaching retirement and received good compensation packages, or a sum of money to cover several years of pension.

\section{B. Process of getting there}

Following the political changes at the end of the 1980s, the Hungarian water and sewerage services were municipalized having previously been owned and run by the state. The consequence of this municipalization was the fracturing of the industry; 400 companies replaced 28 of the original 33 (there are still five state-run regional companies). Out of the new companies, 90 cover more than 90 per cent of the service area. Some of these new companies employ only one or two people and supply water for single agglomerations. There are also regional companies that supply several counties.

According to the legislation currently in place, utilities cannot be sold. The Hungarian law requires only limited liabilities in private sector investments; not majority ownership. Investment is allowed under the following categories:

- $\quad$ an institution of the local government;

- a company with majority ownership by the local government or state; and

- a concession company, where majority private ownership is permitted.

The regulatory framework and the competition rules were developed by mid-1990s, which helped the various PPP schemes in water and municipal solid waste management services (according to a survey only 12-13\% of water management and MSW collection services are kept by municipalities in-house by 2006). There is no regulation on targets of investments, there are only limitation on national government subsidies (no assets built with national budget subsidies can be sold within ten years).

Each municipality sets water and sewage tariffs. There is a national threshold of water tariffs and municipalities with higher water prices are eligible for state subsidies. Although the tariffs have grown significantly over the last five years, the private providers emphasize that the current water and wastewater treatment price is still well bellow the cost recovery amount. As a result of this, the whole sector is suffering from massive under-investment.

\section{Obstacles to further PPP}

In the cases of Szeged and Debrecen the public debate and exposure surrounding the PPP increased transparency, and this proved to be beneficial to both the workforce and to consumers. In this respect, job losses have been restrained by agreements with the unions, price increases have been moderate (at or slightly above inflation) and the more contentious 
elements of the privatization plans have been either abandoned (Debrecen) or substantially modified (Szeged). The Szeged water privatisation case was later terminated and the French company left the country. In some communal service companies the employees have a minority share of $5-10 \%$, which is a really strong instrument to counterbalance the local government's decisions and might help the actual management.

\section{Polish Model}

\section{POLISH MODEL SUMMARY: EMPHASIS OF PARTNERSHIPS}

The Polish model of PPP in water and sanitation resembles the Hungarian one. However, here a special emphasis of partnership between the public and the private sector has been made. A high 'mortality' of the projects (up to 50 per cent) is expected with this model. However, the quality of the working PPPs can be seen to be models of such partnerships.

\section{A. Current situation}

PPP is considered to be one of the options for the development of water utilities in Poland. Water companies are under municipal ownership in Poland. A municipality has the right to privatize a water company as well as to change the price charged for water services.

At the time of the research there were only five examples of PPP in Poland; although these projects can be considered to be successful, the level of PPP in the country is relatively small considering its size and population. The reasons for this can be found among the legal and financial restrictions that are present, as well as the unwillingness of municipalities to participate in partnerships with the private sector.

There is a high 'mortality rate' among the PPP projects in Poland; about 50 per cent (by the transaction amount) of the planned activities have actually been realized into a partnership. However, the surviving projects demonstrate the viability of such partnerships and different scales of improvements that are possible in all spheres of activities.

In all five cases the selling process has taken place through negotiations (usually these took several years, which increased the transaction costs of the projects). The negotiation period was increased partially due to the lack of developed legislation on the selling process. This could be explained by the overall approach towards privatization chosen by Poland, namely a search for strategic investors.

Due to the limited number of PPP in water utilities, the public perception in Poland is difficult to evaluate. However, the example of the energy sector, where several state companies were privatized, shows to some extent negative attitudes towards PPP. In Gdansk at the beginning of the company's activities there were some public complaints concerning privatization issues. However, since the utility has been operating for almost 10 years, it is rather the deterioration of services that will bring public attention to the fact that water is supplied by a private operator and not the private provision of services in itself. 
Private companies' involvement in Poland has improved the managerial efficiency and profitability of companies, as well as the quality of water, water treatment and services. A constructive dialogue with the local population is believed to have helped to establish a balance between water prices and water consumption, the latter of which has decreased significantly. In most of the PPP companies a Client Services Department was created to ensure that adequate communication takes place between the provider and consumers. Most of the water companies, including those with private involvement, have social commitments to the municipality, guaranteeing working places and social care to employees. Dismissed employees are provided with compensation packages.

In addition, all companies showed a substantial level of corporate social responsibility. PPP companies participate in charity projects, develop the social structure of the organization, build schools and sports grounds and provide recreation for employees.

\section{B. The process of getting there}

Since decentralization, the municipality, which is responsible for water provision and sanitation services in the country, makes all final decisions. Partially this responsibility is shared by "powiat" (the local government) which participate in the process of selling the companies.

The calculation of tariffs, as well as the technical and financial development plan of a water company, is developed by the company that is actually operating the utility. After development, the plan is given to the municipality for passing the resolution. The lack of legal regulation on this point creates uncertainty for the municipality. This is because pricing is often a political rather than an economic issue, as everyone, especially when elections are due.

There is a continuing lack of a PPP legal framework in the country that would regulate specific activities of public-private partnerships and conditions of their operation. The legislation on the regulation of the bidding process also needs to be developed to find a way of minimizing the transaction costs, which are now quite substantial.

\section{Obstacles to further PPP}

Regulation of the water sector is the major obstacle for further PPP involvement in Poland. However, as the market in the Czech Republic is becoming saturated, the private companies are now looking towards expanding their activities in Poland.

The small scale of the majority of Polish water companies is a further obstacle to private involvement. There were 4,700 water and wastewater companies in Poland in $2002{ }^{6}$. About 75 per cent of these companies are too small to attract foreign investment by themselves. Amalgamation of these water companies is a political question and can not be resolved easily.

\section{ESTONIAN MODEL}

\section{ESTONIAN MODEL SUMMARY: OPPORTUNITIES FOR THE DOMESTIC PRIVATE SECTOR?}

Because Estonia has only one very recent PPP project, it is difficult to derive a specific 
model. However, this experience will be very useful for small countries with one or two large cities that are of interest to the private sector. The Estonian project also demonstrates how the role of domestic private companies could be invaluable in the ECA region.

\section{A. Current situation}

Although most water utilities in Estonia lack the money and expertise needed for effective operations and investment, they are often too small to attract foreign investors. To resolve this problem, the authorities are considering either continued reliance on international credits or/and donor grants, or the amalgamation of several neighboring towns' water companies into one project to increase the level of operating and maintenance of the water utility. The second option is controversial due to the political nature of the decision. The only water company with PPP is Tallinna Vesi (Tallinn Water Company).

\section{B. The process of getting there}

Public administration reform, started at the beginning of the 1990s, has essentially influenced the development of the water supply and wastewater management. The two state enterprises in Estonia have been decentralized and transferred to municipalities by the Ministry of Environment. Water utilities have been established in practically all municipalities. During the course of reform, several water enterprises were formed into public limited companies, where all shares belong to the municipalities, while a few were privatized by the domestic operators or, in the case of Tallinn, by the foreign consortium. ${ }^{7}$ After Estonia gained complete political independence in 1990-1993, the fall in the amount of water used in industry was mainly attributable to decreased production capacities ${ }^{8}$.

One of the conditions for the private operator candidacy for Tallinna Vesi AS (Tallinn Water) was that it must demonstrate proven successful operations of water utilities in four different countries in Europe. Such moves were viewed as furthering the integration of the country's economy with that of the EU and other western partners on a microeconomic scale and, consequently, importing the western management system into the utility sector ${ }^{9}$.

Following private sector involvement, there were no significant improvements noticed in the company's operations, nor was any substantial technology transfer witnessed. In addition, although after privatization the company became certified according to the ISO 14001 (Environmental Management Standard) [15], the laboratories and most of the equipment required for this certification were designed and acquired before the privatization took place. The Tallinn Water privatization helped to improve the city budget significantly and will raise investments in the future. The numerous water meters installed in flats and households make the saving efforts highly evident and worthwhile. Renovation of water works has also made a notable contribution, as at the moment of transferring the water supply and wastewater treatment from the state to municipalities the existing facilities were old and in poor condition. However, at the time of writing, no capital inflows have been recorded, although the private owner still promises to fulfill its investment plan by the end of the 5-year investment period. Where there is no PPP, the level of technical maintenance is low and there is a strong need for knowledge and technical know-how.

Cost covering water tariffs are rather high in Estonia (1 Euro/per $\mathrm{m}^{3}$ ), putting a significant burden on part of the population, especially in impoverished regions. As a result, some 
municipalities keep the prices for water supply and sanitation at a low level (which is also more of a political than an economic step) via subsidies to the activities of some water companies.

Public opinion has always been important for the Estonian government. Before the 1994 privatization of the Tallinn Water Company, a public opinion poll revealed a favorable attitude of the people in the city to private sector involvement in operations of such a strategically important resource as water. A client services department responsible for the positive image of the company was created after the privatization of Tallinn Water. Currently the client services department is working effectively, answering the complaints of the citizens and providing a full range of services.

About a quarter of employees were dismissed from Tallinna Vesi after International Water acquired 51 per cent of the company's operations in 2001. These people received a compensation package and were able to find another job in the public sector. The press reacted to the dismissal of employees with a number of articles ${ }^{10}$ and continued with revealing financial speculation about Tallinna Vesi.

\section{Major obstacles to PPP}

In Tallina Vesi the initial level of infrastructure and equipment development was higher than the average in the country. The experience of the small-scale water companies in Estonia shows that the water sector can bring about only modest revenues for the private sector. This, coupled with a weak regulative framework and the small-scale of operations, scares away both foreign and domestic private companies. The legislation regulating the private participation in Estonia has been underdeveloped and a concession law does not exist.

\section{Differences between the models of the focus countries}

The varying degree of private sector involvement in water provision in the four focus countries could be explained by a number of factors. Such factors include the differences in:

a) chosen models of privatization; The privatization process in the four countries followed different models; these were reflected in PPP in the countries' respective water sectors. The Czech Republic used a rapid and mass voucher model of privatization. The National Property Fund allocated some shares to towns and municipalities, some to the public and some to other relative parties. The first wave of privatization was expressed in the five rounds of voucher auctions, when every adult citizen could bid for companies with voucher coupons. During the second wave of privatization, major investors bought up public shares. As soon as they became owners of the water companies, three-quarters of municipalities separated the infrastructure from operations and sold the latter. Estonia, Hungary and Poland chose the direct privatization method and applied the case-by-case water company sale approach. In Estonia the privatization of the only PPP water company, Tallinna Vesi (Tallinn Water Company) represents part of the country's democratic reforms. Hungary and Poland based their overall privatization on sales to strategic investors and opening up the process of privatization to foreign investors ${ }^{11}$.

b) regulation; The regulating framework is another important differentiating factor among the focus countries in their approaches towards PPP. It is also considered as one of the main obstacles to deeper PPP. For a long time there was no concession law 
in the Czech Republic, thus current PPP is based on leasing contracts, with private companies owning a share in operations solely (as in Prague) or together with municipalities. Under Hungarian law, local governments are not permitted to sell the physical infrastructure of the water sector. The law insists that a local council must own a majority of shares if it participates in any joint venture, and this constrains the percentage that can be owned by the multinationals. In Poland there is no specific law regulating the questions of ownership of water infrastructure. As a result, there is still uncertainty whether the private operator can own the infrastructure or whether it should still be owned by the municipality.

a) size of individual water company; In the Czech Republic, Estonia and Hungary decentralization resulted in a large number of small municipalities being responsible for the water supply and wastewater treatment. Most of these water and sanitation companies are too small to attract the foreign private investor considering the scale of profitability. For example, in Estonia the average number of employees in water companies is 20 to $30{ }^{12}$. Integration by mandatory amalgamation and assignment of regional service competencies to intermediary level of government are typical solutions, as in Poland.

- tariff levels; In the Czech republic the water prices went up steeply in the early 1990s. By 1993, all subsidies had been removed since water tariffs reached the cost recovery levels. Thus, private operators could come and work. By contrast, in Poland and Hungary the prices, although they have been increasing significantly, still did not reach the cost recovery levels.

b) state of infrastructure before the transition period. Historically, in the Czech Republic there was a well-developed water infrastructure, while in Estonia, Hungary and Poland the coverage of the sewage network in particular was significantly less. The maintenance of this infrastructure was also much better in the Czech Republic; thus, the state of the assets was in a much better shape, so attracting more bids.

c) the role of the consumers and trade unions. Polish and Hungarian trade unions have been traditionally strong and influential. Hungarian government officials favor the unions as they are said to 'help to fight corruption' ${ }^{13}$. Thus, during the water sector privatization in these two countries the unions played an important role in monitoring the decision-making process. Some of the PPPs did not take place because of the particular attention that was paid to the trade unions in Poland.

\section{Impacts of PPP on financial performance and levels of service}

The impact of PPP on financial performance and levels of service in the water sector has been mixed, varying from country to country. International private operators were able to transform water utilities from inert Soviet-type organizations into more dynamic enterprises through increased managerial efficiency, personnel training, in some cases technology transfer and by fostering effective relationships with the suppliers.

However, according to this study no significant variation in efficiency was observed between the public and private operations in the Czech Republic, Poland and Estonia ${ }^{14 .}$ In fact, many of the government representatives in first tier EU accession countries, whom the authors interviewed believe that the same levels of operating efficiency can be achieved without private sector participation (perhaps due to the high initial level of existing infrastructure in the focused countries). In the countries of the ECA region, where PPP could bring about significant improvements in efficiencies, there is an absence of the necessary enabling 
environment, accompanied by a lack of transparency; this situation is further exacerbated by corruption.

Nevertheless an improvement in customer relations has been the most noticeable change in the focus countries. In addition, a decrease in water leakages was reported in almost all cases, coupled with an increased percentage of billed customers and collected fees.

\section{Obstacles to PPP involvement}

A restrictive legal framework that does not allow for majority private ownership or particular types of contracts (such as concessions), is one of the major obstacles for PPP in the region. Existing PPP (for example, that in Yerevan) shows that an imbalanced legal base can create problems with the signed contract.

For the majority, and even for the most advanced countries such as Poland, high transaction costs could limit the number of PPP projects. Lengthy preparation times were found to be one of the major obstacles in the course of developing PPP projects, due to the lack of experience of the governmental sector in tendering and dealing with water sector contracts.

Current obstacles for PPP involvement also include EU grants requirements, which demand no more then a certain percentage of private ownership for a municipality to be eligible for the EU accession funds. The same requirements exist for the government subsidies, thus implicitly discouraging municipalities from selling their assets.

While considering a privatization option, municipalities have increasingly started to look at other alternatives besides PPP, basing their decisions on a case-by-case basis. Thus, competition exists not only among the international water companies; there is also a trend emerging that reflects growing competition between the public and private sectors.

\section{Conclusions and recommendations}

This paper has presented a number of models of PPP in the water sector that are already working in the ECA region and could be used by other ECA countries. The experience of the focus countries shows that the PPP transformed water utilities into more dynamic businesses. Involvement of the private partners helped to rationalize water companies, increasing efficiency and decreasing the unit cost of service through:

- increased managerial efficiency and personnel training (Gdansk, Budapest, Szeged, Prague, Tallinn);

- technology transfer (Gdansk, Budapest); and

- re-negotiation with suppliers (Czech water companies).

Moreover, an increased focus on customers, improved customer relations and increased billing and collection rates were noted in all studied PPP cases. Leakages were reported to have declined (particularly in Prague). In a few cases the quality of water also increased (Poland). Technology transfer was a positive outcome in some cases (Hungary and Poland) but negligible in others (Czech Republic and Estonia), depending on the initial physical condition of the country's infrastructure. It is worth pointing out that the private sector in the 
entire region, is interested only in operating assets rather than becoming involved in infrastructure capital investments.

Nevertheless, there are a few expectations that have not been met through PPPs. These include a lack of infrastructure investments commitment on the side of the private partners, sanitation being the most neglected area in this respect. It was noted that whilst in Poland and Hungary there is a clear idea of partnership between the municipalities and the private operators, in the Czech Republic more emphasis was put on privatization rather than on partnership per se.

In the Czech Republic, despite a record number of PPP projects implemented, municipalities lack the capacity for negotiating contracts with professionals from the private sector. The high number of projects in this country is a factor of the privatization model chosen, adequate tariff size and the condition of infrastructure. The overall level of interest in the sector depends upon its ability to provide a commercial return to the private sector (Czech Republic).

Thus, taking into account the above experiences, in order to form a positive perception of PPP in water in the region, the following should be taken into account:

- Transparency is needed in tendering to help avoid a negative public perception of PPP (Czech Republic);

- Increased quality of water and services is the strongest factor influencing the public's perception.

- A planned employee reduction strategy helps to avoid labor union problems (Budapest, Tallinn).

- Companies that participate in community life have a better image (Gdansk, Budapest)

- It is important to be aware of the political cycles (Tallinn).

Certainly, conditions in each country differ; however, predictions for the most suitable model could be made depending on a particular country's chosen pace and the type of private sector participation that it wishes for its water and sanitation sector

\section{Lessons learned}

While there is a general agreement that private sector participation can bring about improvements in the water sector, such an approach would need to be introduced gradually and take into account the wide disparities within the region. The following lessons were drawn from the research:

1. Private sector participation is only one option for dealing with the water sector where the goal is to improve service efficiency and access to investment funds. Corporatization is another option, which seems to work in some countries in the region.

2. If the goal of PPP is private investment, then there should be no separation of operational and infrastructure assets. However, if improvement of management and technology transfer is the goal, then lease and O\&M contracts are well suited for the ECA region.

3. An enabling legal environment needs to be put in place before launching PPP in order to avoid complications later in the process. In fact, PPP is only possible/ useful to the degree that it is supported by the local framework. A good legal framework, allowing different PPP options and clearly specifying the rules of play, improves opportunities for 
investment. The transfer of former state owned assets to municipalities is a critical step for establishing autonomous local governments and to lay down the foundations of diverse, efficient forms of service provision, together with the development of competition rules and procedures.

4. The general perception of privatization influences the acceptance of PPPs.

5. Reforms are required for most of the water utilities in order to generate internal cash for operations. Funding from the central government and/ or donors/ IFIs is required for rehabilitation of the system. External support is needed for almost all countries in the region. Such support ranges from sector reform and putting in place institutional and legal frameworks to infrastructure rehabilitation and expansion of financing.

6. Municipalities need to have a greater technical and legal capacity to negotiate contracts with international private companies. It is important to explain to the decision-makers the consequences of, and parties' responsibilities to, each type of contractual agreement. If this is not feasible, advisory regulators need to be established to consult with and advise municipalities on partnerships with the private sector.

7. The public sector is the primary provider of capital and not the private sector in the ECA region, because the infrastructure ownership was kept by the local governments.

Governmental control should be improved, specifically in order to foresee the consequences a particular contractual arrangement. This is especially the case if the Czech model of water sector privatization is chosen.

8. Applying subsidies should be considered, along with setting realistic prices for water, depending on the affordability of water by an average household in the country concerned.

9. The condition of infrastructure is an important factor in terms of encouraging the interest of the private sector. Thus, a municipality that invests in the rehabilitation of its water system can attract a better strategic investor to expand coverage of water and sanitation services.

10. The amalgamation of small municipalities into associations will foster PPP in the countries of group 1 . This will not only allow economies of scale, but will also ensure efficient and effective management; although it is also recognized that the amalgamation of fragmented local governments also has political obstacles, so presently the solution is integration by the markets through service contracts.

11. Over-fragmentation during decentralization should be accounted for when considering the PPP that is expected to follow that decentralization. This can help avoid the need for amalgamation later on. 


\section{References}

1. Bennett, Elizabeth; Peter Grohmann \& Brad Gentry (1999) - Public-Private Partnerships for the Urban Environment, Options and Issue - PPPUE Working Paper Series Volume I - UNDP / YALE

2. Sohail, M., Gentry, B. and Maslyukivska, O. (2003) Private Sector Participation in Municipal Water Services in Central and Eastern Europe and Central Asia, Facing a Crisis of Confidence in Private Sector Participation in the Water Sector: Measures to Overcome Obstacles to more effective PSP, OECD and the World Bank, Vienna, Austria, July 2003.

3. Mel Huang (2001) Local Government Brief, From Monopolies to Markets. Privatizing Local Utilities OSI: Budapest.

4. CEORG October/November 2001 Economic survey. www.ceorg-europe.org

5. Shanker, A. \& Rodman, L. (1996) "Public-Private Partnerships", Journal of the American Water Works Association, 88 (4) pp 102-107,

6. Roman M., Kloss-Tribaczkewicz H. (2002) Wskazniki charakteryzujace wodociagi i kanalizacje w polskich miastach w latach 1992-2000 // Samorzad terytorialny. - nr.11. - 2002. - stor. 55

7. Kruusimagi, Kristjan (2002) State of Water Supply and Wastewater Sector in Estonia // Water Sector Development in the Baltic States, Material of the conference, Palanga, 24-25 January 2002.

8. Since the economy of Estonia was still dependant on the centralized economics formed in the Former Soviet Union (FSU).

9. Mel Huang (2001) Local Government Brief, From Monopolies to Markets. Privatizing Local Utilities OSI: Budapest. pp. 1-3 and 6-12.

10. Lobina, Emanuele. (2001) Water privatisation and restructuring in Central and Eastern Europe, 2001. Public Services International Research Unit, University of Greenwich. 33p, - pp.7-8.

11. The World Bank (2002). Analysis and Lessons for Eastern Europe and the Former Soviet Union, Transition: The First Ten Years. The International Bank for Reconstruction and Development/The World Bank.

12. Kruusmagi K. (2002). State of the Water Supply and Wastewater Sector in Estonia, Water Sector Development in the Baltic States. Conference materials: Palanga, 2002.

13. Personal Interview with Ms Judit Zalatnay, environmental analyst, State Privatization and Holding, Hungary. Conducted on May 24, 2003

14. OECD/DANCEE (2003) Models of Water Utilities reform in the Central and Eastern European Countries. Lessons to be learned for Reforms in the NIS. Final Report.

15. ISO 14001:2004. Environmental management systems - Requirements with guidance for use. Edition: 2. $-2004 .-23$ p. 